\title{
Underwater archaeology and submerged landscapes in Western Australia
}

Jonathan Benjamin ${ }^{1}$, Michael O’Leary ${ }^{2}$, Ingrid Ward ${ }^{1,3}$, Jorg Hacker ${ }^{4,5}$, Sean Ulm ${ }^{6}$, Peter Veth ${ }^{7}$, Mads Holst ${ }^{8}$, Jo McDonald ${ }^{7}$, Peter J. Ross ${ }^{1} \&$ Geoff Bailey ${ }^{1,9, *}$

This research aims to explore the submerged landscapes of the Pilbara of Western Australia, using predictive archaeological modelling, airborne LiDAR, marine acoustics, coring and diver survey. It includes excavation and geophysical investigation of a submerged shell midden in Denmark to establish guidelines for the underwater discovery of such sites elsewhere.

\section{Introduction}

Since $65000-50000$ years ago - the currently accepted earliest date range for human entry into Australia and New Guinea (Veth 2017) —one third of the continental land mass has been drowned by post-glacial sea-level rise (Figure 1). Based on work being conducted in other parts of the world, there is good reason to suppose that this drowned territory offered attractive resources for human occupation, and that some palaeoenvironmental and archaeological features of this landscape have survived inundation and can be retrieved by underwater exploration (Benjamin et al. 2011; Evans et al. 2014; Bailey et al. 2017). Relatively little underwater exploration has so far taken place in Australia. Yet investigations of this type are particularly important here, given that the earliest human colonisation happened during a period when landfall and the earliest processes of settlement and dispersal must have first occurred in coastal territory that is now inundated (Nutley 2014; Ward et al. 2015). This project is the first in Australia to explore systematically the drowned

1 College of Humanities, Arts and Social Sciences, Flinders University, G.P.O. Box 2100, Adelaide, SA 5001, Australia

2 School of Molecular and Life Sciences, Curtin University of Technology, Kent Street, Bentley, WA 6102, Australia

3 School of Social Sciences, Faculty of Arts, Business, Law and Education, Archaeology, The University of Western Australia, M257, UWA, 35 Stirling Highway, Crawley WA 6009, Australia

4 ARA-Airborne Research Australia, PO Box 335, Salisbury South, SA 5106, Australia

5 College of Science and Engineering, Flinders University, GPO Box 2100, Adelaide SA 5001, Australia

6 ARC Centre of Excellence for Australian Biodiversity and Heritage, College of Arts, Society and Education, James Cook University, PO Box 6811, Cairns, QLD 4870, Australia

7 Centre for Rock Art Research and Management, School of Social Sciences, Faculty of Arts, Business, Law and Education, Archaeology, The University of Western Australia, M257, UWA, 35 Stirling Highway, Crawley, WA 6009, Australia

8 Moesgaard Museum, Moesgård Allé 15, 8270 Højbjerg, Denmark

9 University of York, Department of Archaeology, The King's Manor, York YO1 7EP, UK

* Author for correspondence (Email: geoff.bailey@york.ac.uk)

$\ddagger$ The original version of this article was published with Western Australia incorrectly capitalised as western Australia. A notice detailing this has been published and the error rectified in the online PDF and HTML copies. 


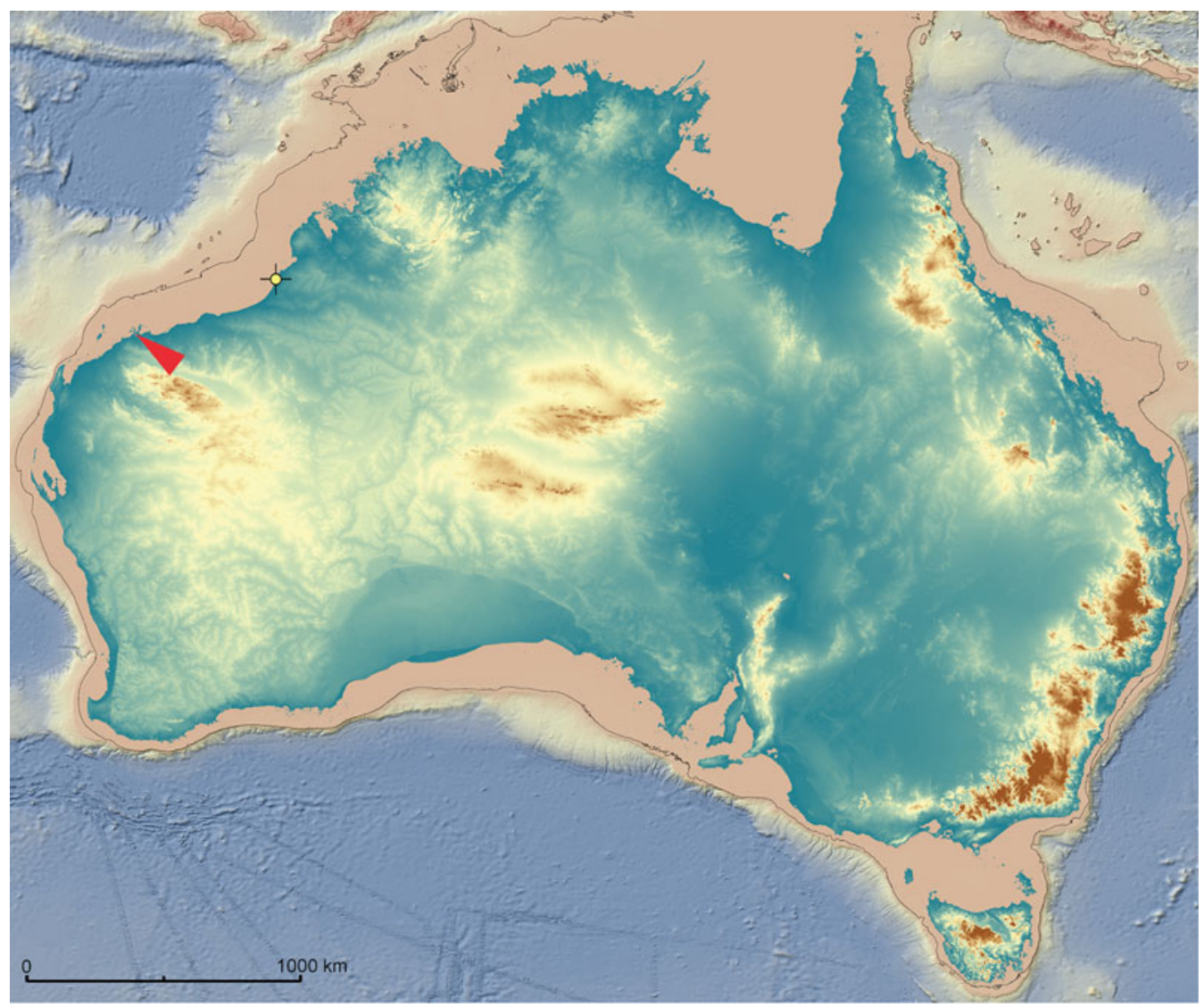

Figure 1. Bathymetric and topographic digital elevation model of the Australian continent and continental shelf. Black line represents the $-130 \mathrm{~m}$ contour, indicating the maximum extent of the Last Glacial Maximum shoreline. The red arrow marks the location of the field area. The yellow circle marks the location of the fish trap shown in Figure 2 (image prepared by Michael O'Leary).

continental shelf, and to integrate the resulting data with the existing on-land terrestrial record of human occupation, using a full range of acoustic, imaging, geoarchaeological and archaeological techniques.

\section{Location}

Our main target area is the Pilbara coast of north-western Australia, near the town of Karratha. Here, a number of existing sources of information make a promising basis for more detailed offshore explorations. A 50 000-year onshore record of terrestrial occupation, including shelf-edge rockshelters on Barrow Island, offers indirect indications concerning the use of the now submerged landscape (Veth et al. 2007, 2017; Ward et al. 2015). Palaeoenvironmental evidence also indicates a higher tidal range and greater estuarine productivity from at least 40000 years ago onwards, when compared to present-day conditions. Thus, marine resources would certainly have been available for exploitation, at least periodically, on now submerged shorelines (Ward et al. 2015; Veth et al. 2017).

(C) Antiquity Publications Ltd, 2018 


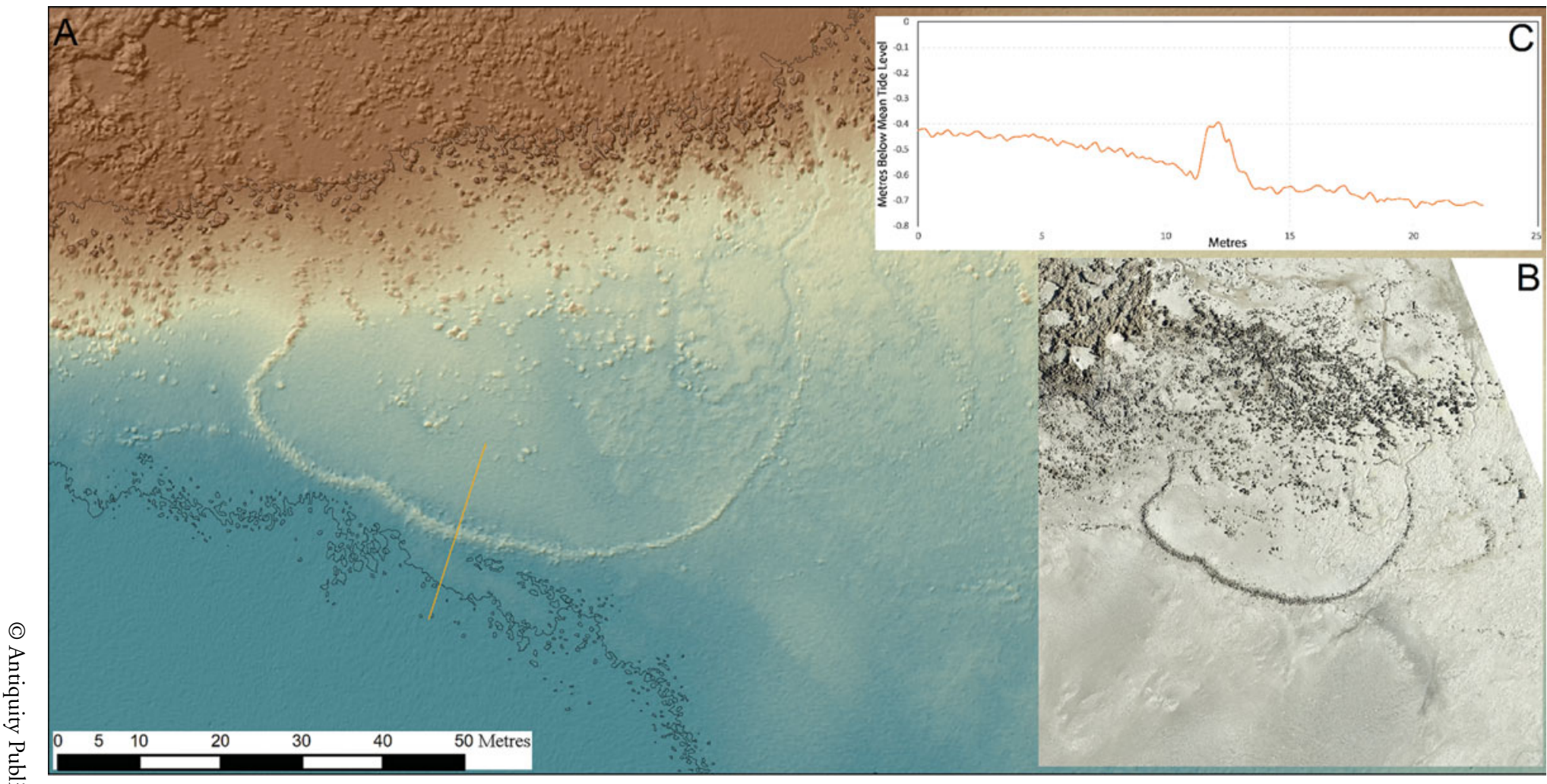

Figure 2. Stone fish-trap at Cape Missiessy, Western Australia: A) terrestrial LiDAR-derived digital elevation model (DEM) surveyed by Airborne Research Australia in 2015 using a full waveform scanning RIEGL Q680i-S; upper and lower contour lines represent mean tide level (MTL) and 1m below MTL, respectively; B) aerial photograph; C) topographic profile across stone fish-trap wall using LiDAR-derived DEM (image prepared by Michael O'Leary).

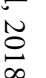

\section{Project Gallery}




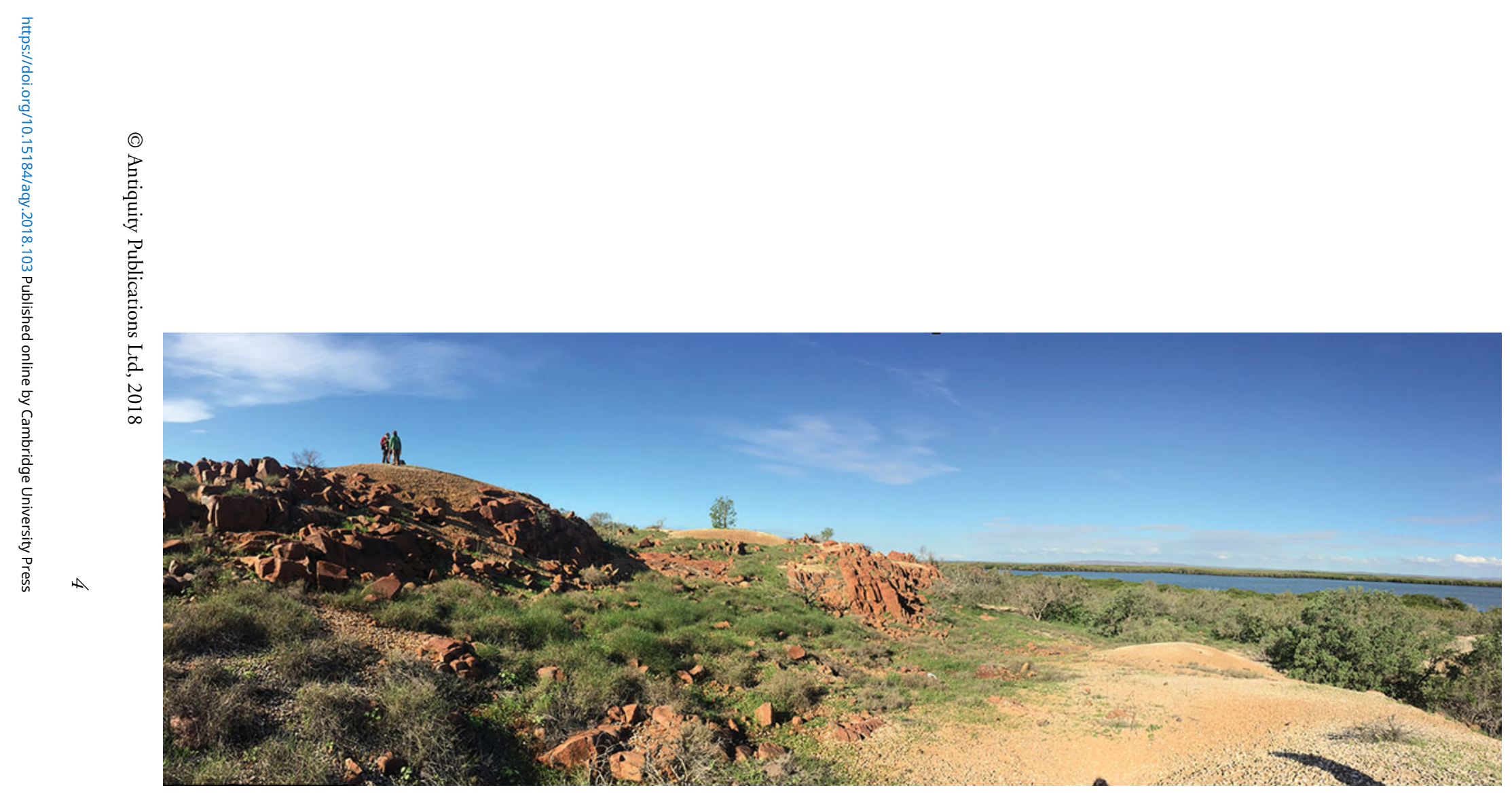

Figure 3. Mounded shell middens on the present-day coastline on West Intercourse Island, southern Dampier Archipelago (photograph by Jo McDonald). 


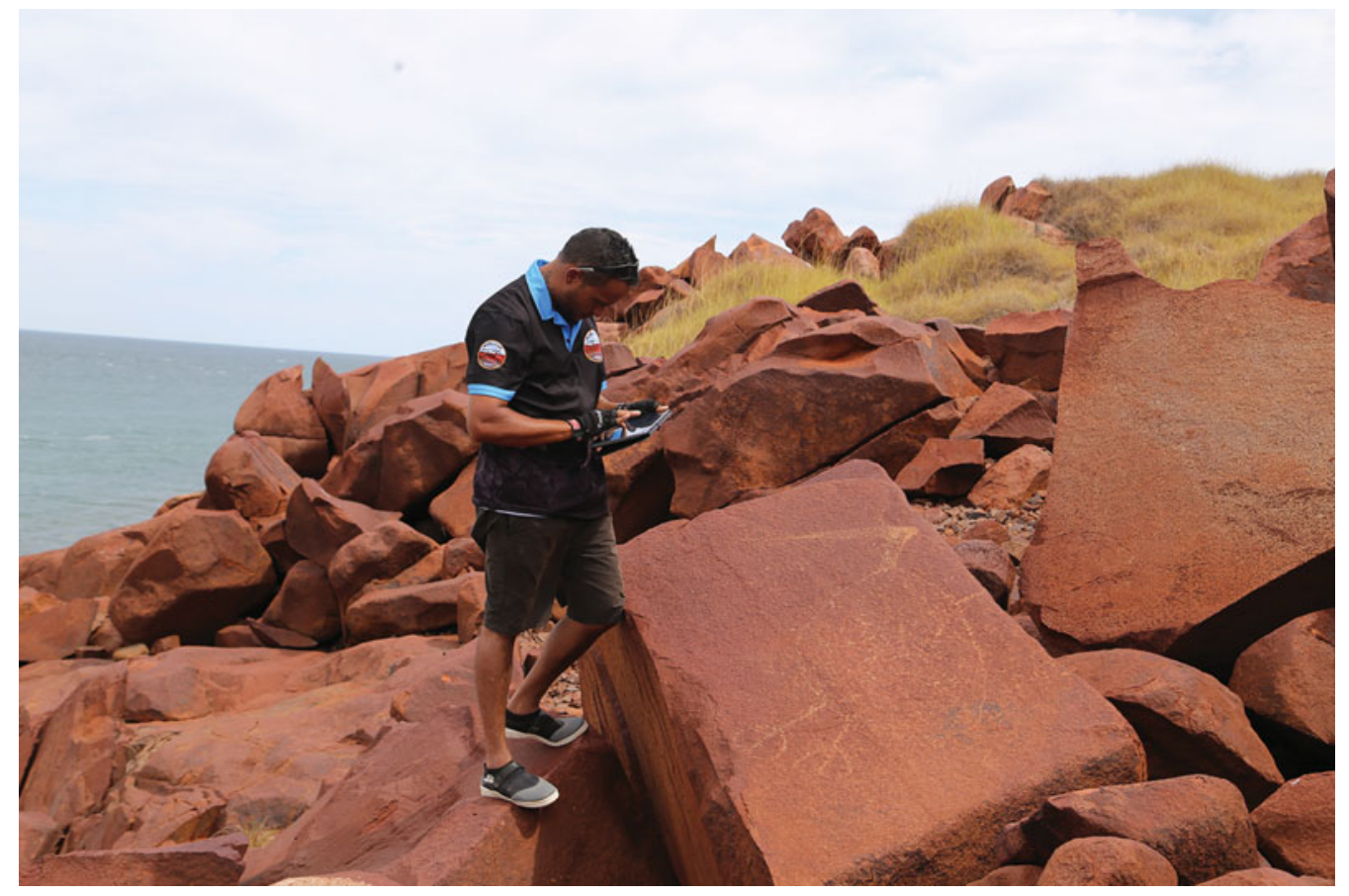

Figure 4. Murujuga Aboriginal Corporation ranger recording an engraving of a pelican on Enderby Island, outer Dampier Archipelago (photograph by Jo McDonald).

High-resolution bathymetry is already available over some parts of the shelf, showing submerged shorelines and other relict features of the ancient landscape (Brooke et al. 2017), along with satellite imagery indicating stone fish-traps close to the present shoreline. Early stone fish-traps (Figure 2), Holocene mounded shell-midden sites (Figure 3) and many thousands of rock engravings on the present-day coast (Figure 4) provide a basis for predictive modelling of underwater archaeological remains (McDonald \& Veth 2009; Ward et al. 2013). There is also a substantial body of Indigenous knowledge about this 'sea country' throughout coastal Australia, including memories of now inundated traditional land (Bradley 2010; Nunn \& Reid 2016).

\section{Methodology}

The project will take a staged approach to the exploration of the underwater landscape, including innovative techniques previously untested in archaeological investigations. These include the use of high-resolution airborne topographic and bathymetric LiDAR to produce a seamless terrain model of the surface topography onshore and offshore, and the analysis of an underwater shell midden in Denmark to develop an understanding of the acoustic and geoarchaeological signals associated with this type of deposit. The Pilbara research will be conducted in collaboration with traditional owners represented by Murujuga Aboriginal Corporation and the Australian Research Council Linkage Project, 'Murujuga: Dynamics of the Dreaming'. 


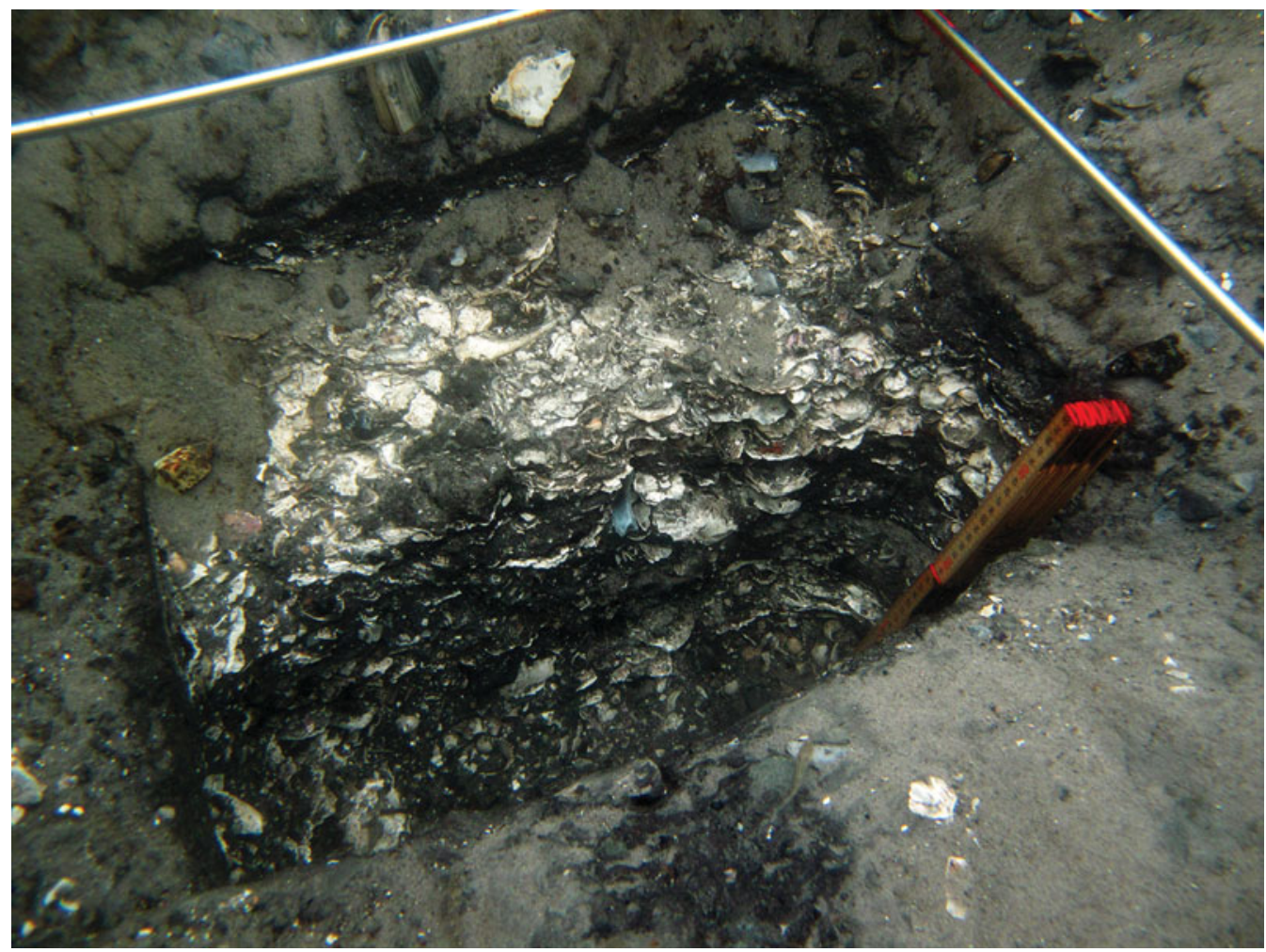

Figure 5. Excavation of an underwater shell midden at Hjarnø in Denmark (original photograph by J. Frederiksen, reproduced courtesy of $C$. Skriver).

The first step is to compile information on known onshore archaeological sites in the Pilbara region, their palaeoenvironmental and topographic associations, and to examine existing offshore marine survey data. This will be amplified using airborne survey combining bathymetric LiDAR equipment capable of achieving sub- $0.5 \mathrm{~m}$ scale mapping to water depths of approximately $10 \mathrm{~m}$, and high-resolution topographic LiDAR and stereoimaging cameras. The objective here is to provide a detailed understanding of known onshore archaeological sites in their topographic and landscape setting, and to develop a preliminary understanding of the offshore bathymetry and underwater features of potential archaeological and palaeoenvironmental significance.

A second step is the analysis of the underwater archaeological shell midden of Hjarnø in Denmark, one of the few such middens known to exist anywhere in the world. Previous excavation established this to be a midden of the classic Ertebølle culture (approximately 8000 years old), associated with gjytta (peat deposits), a hearth area enclosed within the shell remains, flint and antler artefacts, food remains (including bones of fish, land mammals and marine mollusc shells), and wooden artefacts, including remains of a log boat and decorated wooden paddles (Figure 5) (Skriver et al. 2017). The objective at Hjarnø is to combine coring and new excavation of the submerged archaeological deposits

(C) Antiquity Publications Ltd, 2018 


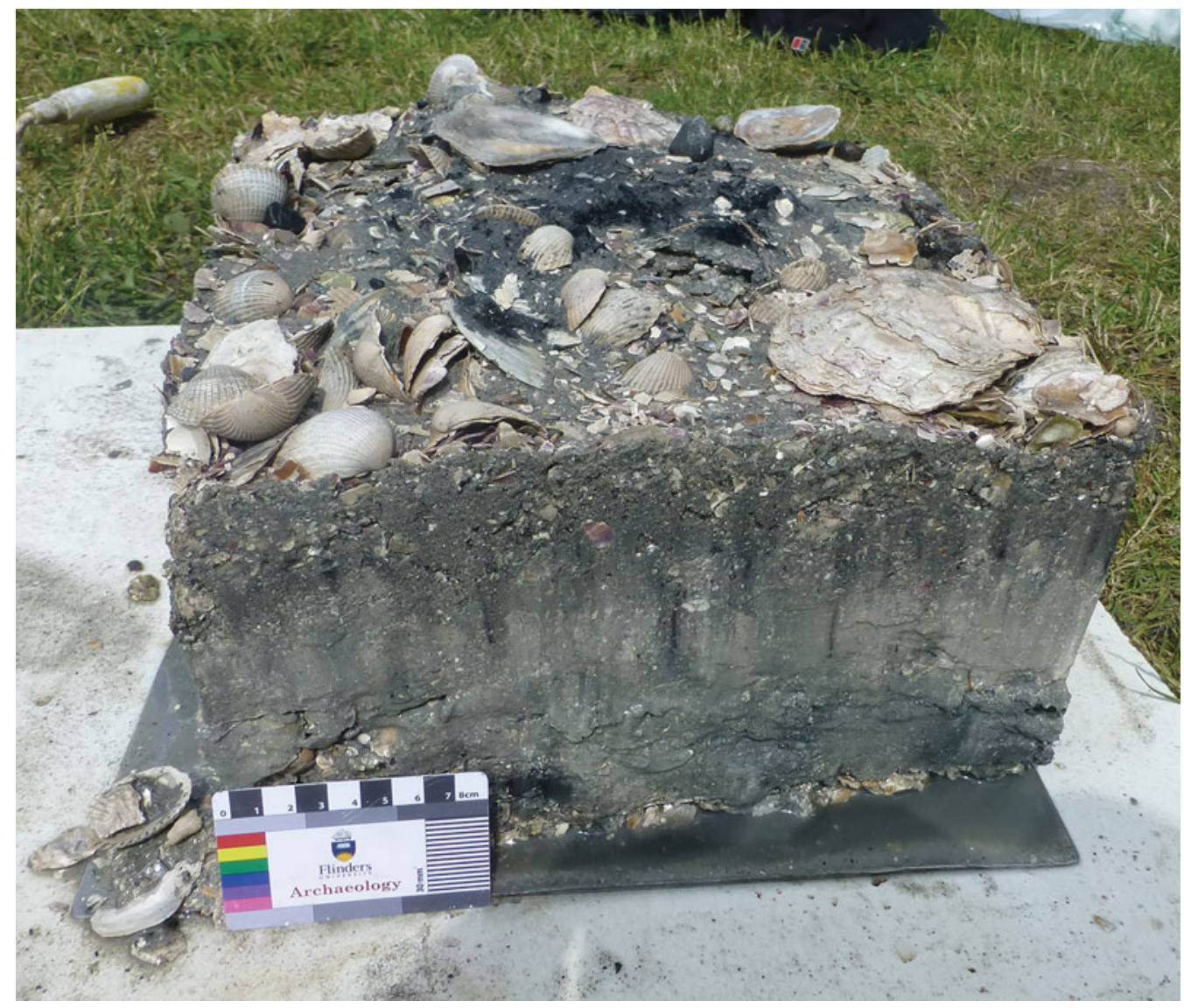

Figure 6. Block removal of an undisturbed section of the Hjarno shell midden deposit and potential hearth feature (photograph by Ingrid Ward).

and their associated sediments with geophysical survey using sidescan sonar and highresolution three-dimensional bathymetry. Thus, we intend to establish the acoustic and geoarchaeological signals associated with submerged and buried midden deposits (Figure 6). We expect the results of this work to feed into the search for underwater archaeological material in the Pilbara region, and to be of global interest and relevance to underwater research.

A third step is to locate and map potential underwater targets in the Pilbara region, initially in the intertidal zone and then farther offshore. Targets of particular interest are submerged shorelines, coastal dunes, estuarine and tidal river channels, cliff lines, rock overhangs and identifiable upstanding stone features, such as fish traps and hut foundations - the latter known from archaeological research on land. Survey will be conducted initially with sidescan sonar at coarse resolution to identify targets. Subsequent survey will use high-resolution sidescan and three-dimensional multibeam bathymetry, followed by ground-truthing using a stereo-drop camera, hand and gravity

(C) Antiquity Publications Ltd, 2018 
coring, divers (where appropriate) and collection of sediment samples for geochemical, micropalaeontological and dating analyses.

\section{Expected outcomes}

This research will provide: a) the first detailed modelling of an underwater archaeological landscape in Australia; b) a morphometric and marine geophysical template for the identification of key cultural features, including the development of a Danish model for the prospection and identification of submerged shell middens; c) the basis for comparison with similar research being conducted elsewhere in the world. The research will also promote investigation more generally of the underwater archaeology associated with 'Sea country' traditions.

\section{Acknowledgements}

The project is supported by the Australian Research Council's Discovery Projects funding scheme (DP170100812), with additional support from the ARC Dynamics of the Dreaming Linkage (LP140100393), Flinders University and the Hackett Foundation of Adelaide.

\section{References}

Bailey, G.N., J. Harff \& D. Sakellariou (ed.). 2017. Under the sea: archaeology and palaeolandscapes of the continental shelf. Heidelberg: Springer. https://doi.org/10.1007/978-3-319-53160-1

Benjamin, J., C. Bonsall, K. Pickard \& A. Fischer (ed.). 2011. Submerged prehistory. Oxford: Oxbow.

Bradley, J. 2010. Singing saltwater country: journey to the songlines of Carpentaria. Sydney: Allen \& Unwin.

Brooke, B.P., S.L. Nichols, Z. HuANG \& R.J. BeAman. 2017. Palaeoshorelines on the Australian continental shelf: morphology, sea-level relationship and applications to environmental management and archaeology. Continental Shelf Research 134: 26-38. https://doi.org/10.1016/j.csr.2016.12.012

Evans, A., N. Flemming \& J. Flatman (ed.). 2014. Prehistoric archaeology of the continental shelf: $a$ global review. New York: Springer. https://doi.org/10.1007/978-1-4614-9635-9

McDonald, J.J. \& P. Veth. 2009. Dampier Archipelago petroglyphs: archaeology, scientific values and National Heritage Listing. Archaeology in Oceania 44: 49-69. https://doi.org/10.1002/j.18344453.2009.tb00068.x

Nunn, P.D. \& N.J. Reid. 2016. Aboriginal memories of inundation of the Australian coast dating from more than 7000 years ago. Australian Geographer 47: 11-47. https://doi.org/10.1080/00049182.2015.1077539
Nutley, D. 2014. Inundated site studies in Australia, in A. Evans, N. Flemming \& J. Flatman (ed.) Prehistoric archaeology of the continental shelf: a global review: 255-73. New York: Springer. https://doi.org/10.1007/978-1-4614-9635-9_14

Skriver, C., P. Borup \& P.M. Astrup. 2017. Hjarnø Sund: an eroding Mesolithic site and the tale of two paddles, in G.N. Bailey, J. Harff \& D. Sakellariou (ed.) Under the sea: archaeology and palaeolandscapes of the continental shelf: 131-43. Cham: Springer. https://doi.org/10.1007/978-3-319-53160-1_8

VeTH, P. 2017. Breaking through the radiocarbon barrier: Madjedbebe and the new chronology for Aboriginal occupation of Australia. Australian Archaeology 83: 165-67. https://doi.org/10.1080/03122417.2017.1408543

Veth, P., K. Aplin, L. Wallis, T. Manne, T. Pulsford, E. White \& A. Chappell. 2007. The archaeology of Montebello Islands, north-west Australia: Late Quaternary foragers on an arid coastline (British Archaeological Reports International series 1668). Oxford: Archaeopress.

Veth, P., I. Ward, T. Manne, S. Ulm, K. Ditchfield, J. Dortch, F. Hook, F. Petchey, A. Hogg, D. Questiaux, D. Demuro, L. Arnold, N. Spooner, V. Levchenko, J. Skippington, C. Byrne, M. Basgal, D. Zeanah, D. Belton, P. Helmholz, S. Bajkan, R. Bailey, C. Placzek \& P. KENDRICK. 2017. Early human occupation of a maritime desert, Barrow Island, north-west Australia. Quaternary Science Reviews 168: 19-29. https://doi.org/10.1016/j.quascirev.2017.05.002 
Ward, I., P. Larcombe, K. Mulvaney \& C.A. Fandry. 2013. The potential for discovery of new submerged archaeological sites near the Dampier Archipelago, Western Australia. Quaternary International 308-309: 216-29.

https://doi.org/10.1016/j.quaint.2013.03.032
Ward, I., P. Larcombe \& P. Veth. 2015. A new model for coastal resource productivity and sea level change: the role of physical sedimentary processes in assessing the archaeological potential of submerged landscapes from the northwest Australian coastline. Geoarchaeology 30: 19-31. 


\section{ERRATUM}

\section{Underwater archaeology and submerged landscapes in Western Australia_ERRATUM}

Jonathan Benjamin, Michael O’Leary, Ingrid Ward, Jorg Hacker, Sean Ulm, Peter Veth, Mads Holst, Jo McDonald, Peter J. Ross \& Geoff Bailey

https://doi.org/10.15184/aqy.2018.103, Published by Cambridge University Press, 27 June 2018.

In the above article, Western Australia was incorrectly capitalised as western Australia. The article has been updated online with the correct capitalisation throughout.

\section{Full citation}

Benjamin, J., M. O’Leary, I. Ward, J. Hacker, S. Ulm, P. Veth \& G. Bailey. 2018. Underwater archaeology and submerged landscapes in Western Australia. Antiquity Project Gallery 92(363), https://doi.org/10.15184/ aqy.2018.103 